\title{
COMPOSITION AND ABUNDANCE OF ZOOPLANKTON IN THE LIMNETIC ZONE OF SEVEN RESERVOIRS OF THE PARANAPANEMA RIVER, BRAZIL
}

\author{
SAMPAIO, E. V., ${ }^{1}$ ROCHA, O., ${ }^{2}$ MATSUMURA-TUNDISI, T. ${ }^{3}$ and TUNDISI, J. G. ${ }^{3}$ \\ ${ }^{1}$ Programa de Pós-graduação em Ecologia e Recursos Naturais, Universidade Federal de São Carlos, C.P. 676, \\ CEP 13565-905, São Carlos, SP, Brazil \\ ${ }^{2}$ Departamento de Ecologia e Biologia Evolutiva, Universidade Federal de São Carlos, C.P. 676, \\ CEP 13565-905, São Carlos, SP, Brazil \\ ${ }^{3}$ Instituto Internacional de Ecologia, Rua Bento Carlos, 750, CEP 13560-660, São Carlos, SP, Brazil \\ Correspondence to: Edson Vieira Sampaio, Estação de Hidrobiologia e Piscicultura de Três Marias, Codevasf, C.P. 11, \\ CEP 39205-000, Três Marias, MG, Brazil, e-mail: cvsf3m@progressnet.com.br \\ Received March 4, 2002 - Accepted April 9, 2002 - Distributed August 31, 2002
}

(With 8 figures)

\begin{abstract}
The species composition and abundance of the zooplankton community of seven reservoirs of the Paranapanema River, located between $22^{\circ} 37^{\prime}-23^{\circ} 11^{\prime} \mathrm{S}$ and $48^{\circ} 55^{\prime}-50^{\circ} 32^{\prime} \mathrm{W}$, were analysed over four periods, in the year of 1979. The zooplankton community was composed of 76 species of Rotifera, 26 species of Cladocera and 7 species of Copepoda. For a large part of the period under study the Rotifera were dominant, followed by Copepoda. The Piraju and Salto Grande reservoirs, which occupy intermediate positions in the cascade of reservoirs, were richest in species, most of them belonging to Rotifera and Cladocera. In the reservoirs Rio Pari and Rio Novo, lateral to the cascade of reservoirs, a lower species richness was observed, although higher densities of organisms were found than in the other reservoirs located in the main river body. Different rotifer species occurred in succession, being abundant in different periods, with no defined pattern. Among the copepods, Thermocyclops decipiens predominated in the majority of the reservoirs. Ceriodaphnia cornuta was the most abundant cladoceran in the intermediate reservoirs of the cascade, and Daphnia gessneri, Bosminopsis deitersi and Moina minuta, in the reservoirs lateral to the cascade. The most frequent zooplankton species were Notodiaptomus conifer, Thermocyclops decipiens, Ceriodaphnia cornuta cornuta and C. cornuta rigaudi, Daphnia gessneri, Bosmina hagmanni, Keratella cochlearis and Polyarthra vulgaris. Some relationships were found between the trophic state of the reservoirs and the zooplankton community.
\end{abstract}

Key words: Rotifera, Cladocera, Copepoda, reservoirs, Paranapanema River.

\section{RESUMO}

\section{Composição e abundância da comunidade zooplanctônica na zona limnética de sete reservatórios do rio Paranapanema, Brasil}

No presente trabalho, sete reservatórios do rio Paranapanema, localizados entre $22^{\circ} 37^{\prime}-23^{\circ} 11^{\prime} \mathrm{S}$ e $48^{\circ} 55^{\prime}-50^{\circ} 32^{\prime} \mathrm{W}$, foram estudados quanto à composição e à abundância da comunidade zooplanctônica durante quatro períodos do ano de 1979. A comunidade zooplanctônica era composta por 76 espécies de Rotifera, 26 espécies de Cladocera e 7 espécies de Copepoda. Na maioria das épocas estudadas houve predomínio dos Rotifera, seguido por Copepoda. Nos reservatórios Piraju e Salto Grande, intermediários à cascata de reservatórios, ocorreu maior número de espécies, a maioria pertencente aos Rotifera e aos Cladocera. Para os reservatórios Rio Pari e Rio Novo, laterais à cascata, observouse menor número de espécies, porém com maiores densidades de organismos do que os demais reservatórios, localizados no corpo principal do rio. Diferentes espécies de Rotifera alternaram a 
ocorrência, sendo mais abundantes nos diferentes períodos, sem padrão definido. Entre as espécies de Copepoda, Thermocyclops decipiens predominou na maioria dos reservatórios. Em relação aos Cladocera, Ceriodaphnia cornuta foi mais abundante nos reservatórios intermediários e Daphnia gessneri, Bosminopsis deitersi e Moina minuta predominaram nos reservatórios laterais à cascata. As espécies mais freqüentes foram Notodiaptomus conifer, Thermocyclops decipiens, Ceriodaphnia cornuta cornuta e C. cornuta rigaudi, Daphnia gessneri, Bosmina hagmanni, Keratella cochlearis e Polyarthra vulgaris. Algumas relações entre o estado trófico dos reservatórios e a comunidade zooplanctônica foram feitas.

Palavras-chave: Rotifera, Cladocera, Copepoda, reservatórios, rio Paranapanema.

\section{INTRODUCTION}

Species composition and abundance of zooplankton communities can be influenced by a number of physical, chemical and biological factors. In a general way, factors such as temperature (Edmondson, 1965), salinity (Egborge, 1994), pH (Sprules, 1975) and electrical conductivity (Pinto-Coelho et al., 1998) can affect this community with regard to both composition and population density. The size of the water bodies (Patalas, 1971), their trophic state (Gannon \& Stemberger, 1978) and the successional stage (Hutchinson, 1967) also greatly influence the species composition of the zooplankton. However, the factors recognized as the most important by the majority of authors are temperature, quality and availability of food, competition and predation. In natural environments these factors act simultaneously and may also interact to different degrees, modifying the zooplankton structure in different ways.

Temperature controls the reproductive rate, population size and metabolism of many species (Edmondson, 1965). Quality and quantity of food can alter species composition as well as the abundance of the species, since particular organisms are highly selective about the size and the type of phytoplankton they eat (Campbell \& Haase, 1981, provide a good review of the subject). Long-term studies on zooplankton composition have indicated that in tropical regions precipitation and wind are important physical factors affecting zooplankton structure (Matsumura-Tundisi \& Tundisi, 1976; Nogueira \& Matsumura-Tundisi, 1996). Intra and inter specific zooplankton competition can alter population abundance by reducing species fecundity or raising the mortality of juveniles (Smith \& Cooper, 1982). Predation by invertebrates usually has a greater impact upon microzooplankton than on macrozooplankton, frequently reducing the abundance of the former (Zaret, 1980). Predation by fish may affect zooplankton structure, in accordance with the fish feeding mode: selective feeders, by differential capture of organisms, tend to eliminate large species, which are replaced by less vulnerable small forms (Brooks \& Dodson, 1965); filter-feeding planktophage fishes do not actively select their preys and therefore more evasive species avoid predation whereas small forms are captured, thus diminishing zooplankton densities (Drenner et al., 1982).

The dominance of nanophytoplankton (2-20 $\mu \mathrm{m}$ ) is usually observed in oligotrophic environments and large herbivores such as Copepoda, Calanoida and large Cladocera predominate among zooplankton, consuming a large fraction of the algae. In eutrophic systems on the other hand, microphytoplankton (20-200 $\mu \mathrm{m})$, bacteria and colonial algae dominate, and small sized consumers such as Rotifera, small Cladocera and Copepoda, Cyclopoida may become abundant, characterizing a detritic food-chain (Hillbricht-Ilkowska, 1972; Pejler, 1983; Bays \& Crisman, 1983).

According to Hellawell (1978, cited in Abel, 1989), biotic communities respond to pollution or to eutrophication in three main ways: 1 . biomass alters but community structure (species composition and relative abundance) does not; 2 . species remain the same but relative abundances alter and biomass may alter; and 3. species composition and relative abundance alter and biomass may alter.

Eutrophication of freshwaters causes great changes in the structure of zooplankton communities. Many species disappear as a consequence of algal toxins or the clogging of filter-feeding apparatus during algal blooms, especially those of Cyanophyceae, which may have both effects (Infante, 1982; 
Matsumura-Tundisi et al., 1986). Some species such as Brachionus calyciflorus and Bosmina longirostris, having a great ability to utilize colonial Cyanophyceae as food, exhibit a greater tolerance to their blooms (Fulton \& Paerl, 1987), so that they become abundant in such conditions and may be considered bioindicators of eutrophication (Gannon \& Stemberger, 1978; Matsumura-Tundisi, 1999). According to several authors, a number of species found in Brazilian freshwaters may be used as indicators of the trofic state of a body of water; they include: Argyrodiaptomus furcatus, Notodiaptomus iheringi, Moina minuta, Moina micrura, Bosminopsis deitersi, Bosmina hagmanni, Metacyclops mendocinus, Thermocyclops decipiens, Thermocyclops minutus, Brachionus angularis, Brachionus falcatus, Ptygura libera, Asplanchna sp. In most reservoirs in Brazil the zooplankton is dominated by Rotifera, in terms of both, density and species richness (Rocha et al., 1995). Several factors including life cycle traits, feeding mechanisms and metabolism, favour the Rotifera which have competitive advantages over the other main zooplankton groups such as Cladocera and Copepoda (Allan, 1976; Dumont, 1977).

In non-eutrophic lakes in temperate regions the zooplankton are usually dominated by Cladocera species belonging to the Daphnidae family. In tropical regions the Rotifera have been observed to be dominant irrespective of the level of eutrophication thus suggesting that other factors and particularly the zooplanktonic interactions (competition and predation) may be more important. According to Matsumura-Tundisi (1999), reservoirs usually have a larger number of species than natural lakes. The reported variation in species number can be related to such factors as reservoir ageing, residence time, trophic state, biological interactions, endemisms, and even to sampling effects and the expertise of zooplankton investigators (Rocha et al., 1999).

One of the main difficulties in studying loss of biodiversity due to eutrophication is the absence of previous records of species composition, prior to eutrophication. In the case of São Paulo State reservoirs, a pioneer typological study on 23 reservoirs established a base line, comprising a seasonal study of their main physical, chemical and biological characteristics (Tundisi, 1981). Thus in the present work, the existing records for seven reservoirs on the Paranapanema river were reanalysed in detail, with aim of producing as much information as possible about the zooplankton, since some species in that community are good biological indicators.

\section{MATERIAL AND METHODS}

The seven reservoirs in the study are located in the Paranapanema River Basin (Fig. 1). Five of them, Jurumirim, Piraju, Xavantes, Salto Grande and Capivara, constitute a reservoir cascade on the main river. The remaining two, Rio Pari and Rio Novo reservoirs, are located alongside the cascade, on the tributaries of the same names. Rio Pari Reservoir is confluent with Capivara Reservoir, whereas Rio Novo Reservoir is connected by Rio Novo to Salto Grande Reservoir, despite being geographically closer to Jurumirim and Piraju reservoirs. The main morphometric characteristics of the reservoirs are shown in Table 1.

Plankton samples were taken in the most representative limnetic region of each reservoir, at a distance of approximately three kilometers from the dam, at quarterly intervals in 1979; in February, May, August and November. These months are representative of the different climatic periods in the seasonal cycle, mainly distinguished by precipitation, rather than temperature. Water was collected with a suction pump, from the whole water column, moving the collecting tube up and down. Zooplankton and phytoplankton samples were concentrated in nets of $68 \mu \mathrm{m}$ and $20 \mu \mathrm{m}$ mesh respectively. Filtered volumes varied from $175 \mathrm{~L}$ to $365 \mathrm{~L}$ and concentrated samples were preserved in $4 \%$ formalin.

Qualitative analysis of zooplankton was performed under stereoscopic optical microscope at magnifications up to 400 times. Specialized literature was used to identify the organisms. Quantitative analysis of rotifers and nauplii of copepods was performed in a Sedgwick-Rafter chamber, counting between one and five chambers, depending on the abundance, in order to determine the density and relative abundance of all species. Microcrustaceans were counted in sub samples varying from $10 \mathrm{ml}$ to the whole sample, depending on the concentrations of organisms, in reticulated acrylic chambers. Density of organisms were calculated from the volume of water filtered and the size of each sub sample, and expressed as numbers of individuals per cubic meter. 


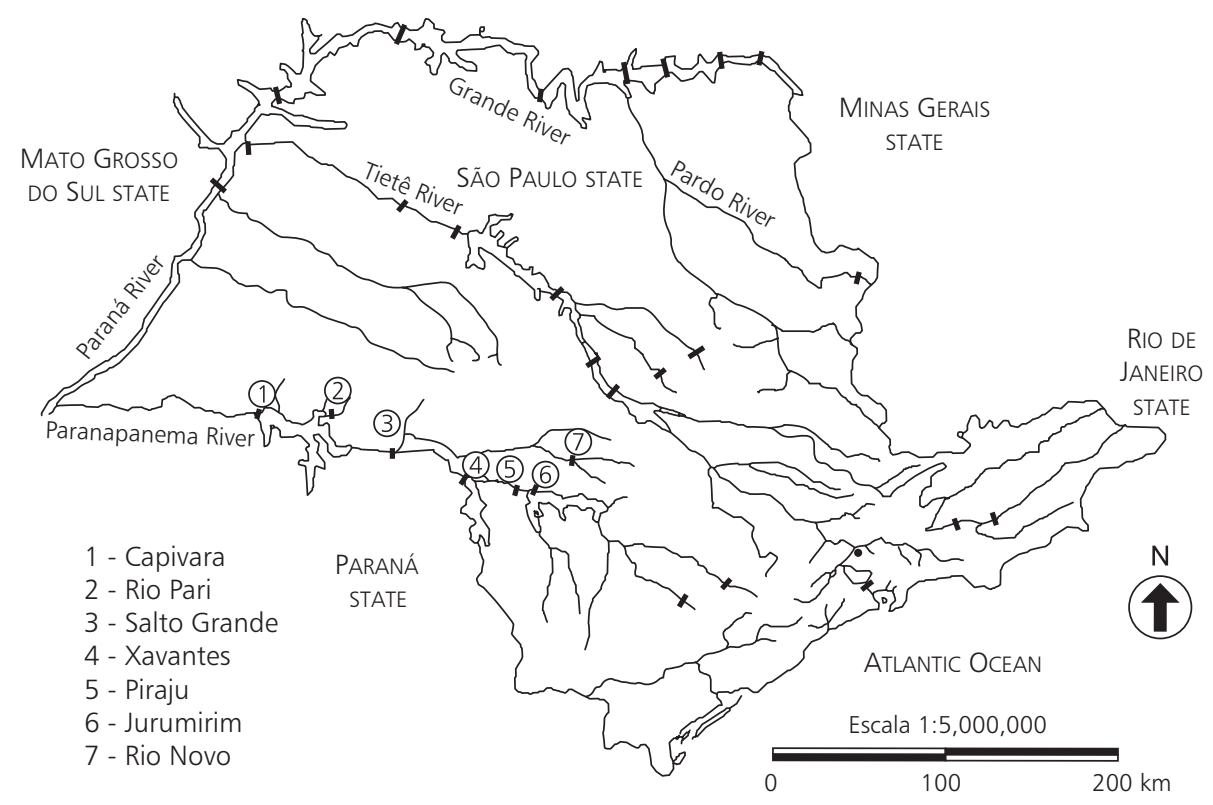

Fig. 1 - Location of the reservoirs studied and also of other dams in the main hydrographic basins of São Paulo State (modified from Tundisi et al., 1988).

In order to determine the relative abundance of the phytoplankton groups present, qualitative and quantitative analyses were performed by counting one milliliter of the concentrated sample in a Sedgwick-Rafter chamber.

Diversity was evaluated using the ShannonWiener index (Pielou, 1975). The Sørensen index (Sørensen, 1948) was used to compare the zooplankton species compositions of the different reservoirs. Species were classified according to their frequency of occurrence as: constant $(50 \%$ or more), common (between $10 \%$ and $50 \%$ ) on rare (below 10\%), as described in Gomes (1989).

For the analysis of dominance and abundance of the species, the criteria proposed by Lobo \& Leighton (1986) were applied: a species was considered abundant when the number of individuals was higher than the mean density of all occurring species, and dominant when their numerical density was higher than $50 \%$ of the total number of individuals present.

Principal component analysis was performed as described in Sneath \& Sokal (1973), using hierarchical abundances of the main plankton species, and aiming to find possible correlations between the phytoplankton groups and zooplankton species, looking simultaneously at the four sampling periods.

\section{RESULTS}

\section{Species composition and diversity}

From 27 analysed samples, a total of 76 species of Rotifera (Table 2), 2 of Copepoda, Calanoida, 5 of Copepoda, Cyclopoida (Table 3) and 26 of Cladocera (Table 4) were recorded. A total of 108 different taxa were identified, including some sub-specific varieties.

The total number of species varied from 12 , in Rio Novo Reservoir, up to 45, in Salto Grande Reservoir. The largest number of species was found in the rainy period (February and November) in Salto Grande and Piraju reservoirs (Table 5). Although the lowest number of species in Rio Novo Reservoir occurred in February, in the other reservoirs the smallest richness of species was found in August, at the end of the dry season.

The values obtained for the ShannonWiener index varied from 1.5 in Xavantes and Rio Novo reservoirs (August) to a maximum of 3.0 in Piraju (February) and Salto Grande (November) reservoirs. 


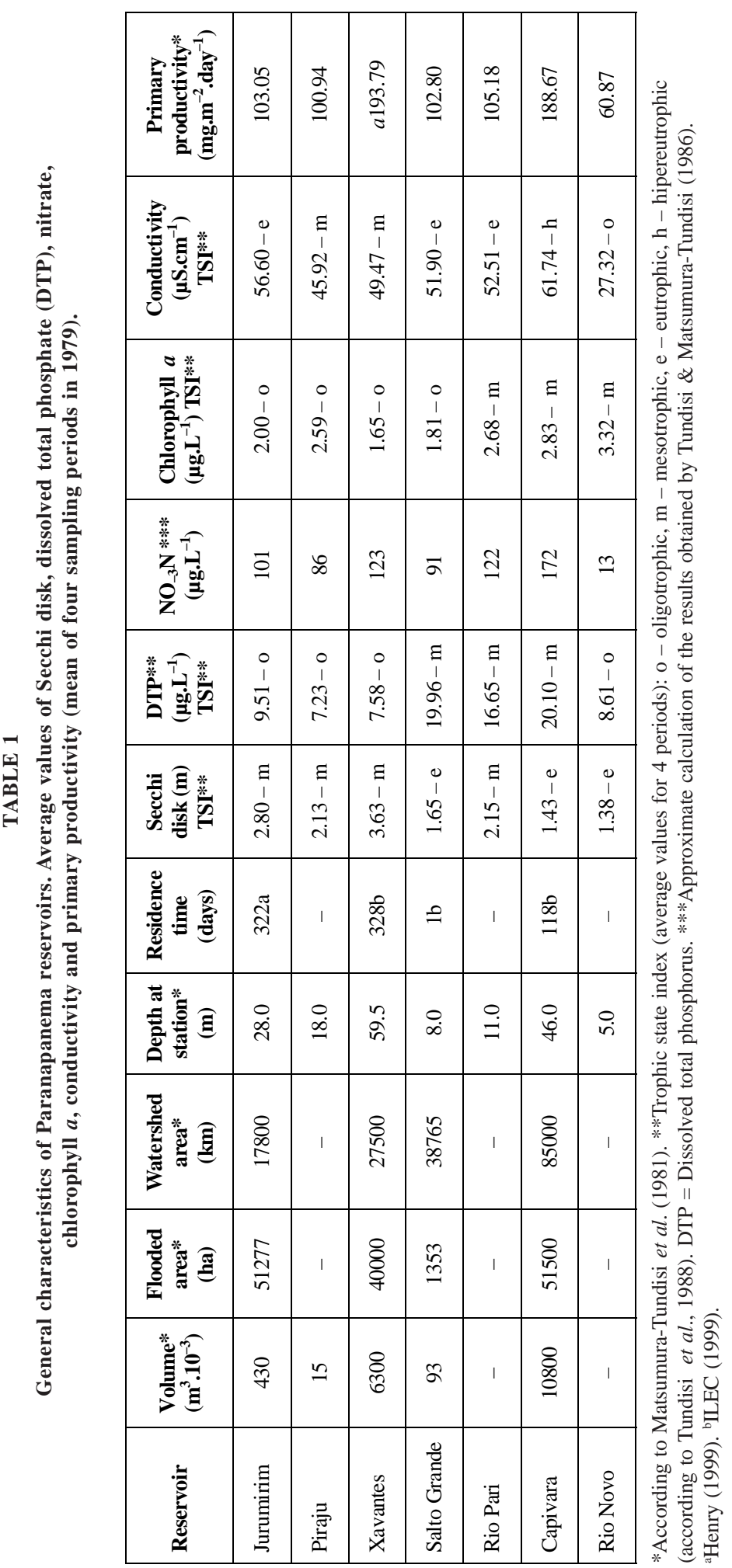


TABLE 2

Species composition of Rotifera in the zooplankton communities of seven reservoirs at Parapanema River, along the year 1979.

\begin{tabular}{|c|c|c|c|c|c|c|c|}
\hline \multirow[b]{2}{*}{ Species } & \multicolumn{7}{|c|}{ Reservoirs } \\
\hline & 羃 & 苛 & 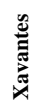 & 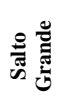 & 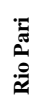 & 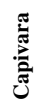 & 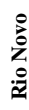 \\
\hline Anuraeopsis fissa & - & - & - & - & + & - & - \\
\hline Anuraeopsis navicula & - & - & + & + & - & - & - \\
\hline Ascomorpha ovalis & + & + & + & + & + & + & - \\
\hline Ascomorpha saltans & - & + & + & + & + & - & - \\
\hline Asplanchna sp. & + & - & - & + & - & - & - \\
\hline Brachionus angularis & - & - & + & - & - & - & - \\
\hline $\begin{array}{l}\text { Brachionus calyciflorus } \\
\text { amphiceros }\end{array}$ & + & - & + & + & - & - & - \\
\hline Brachionus calyciflorus dorcas & + & - & - & - & - & + & - \\
\hline Brachionus caudatus & - & - & - & + & - & + & - \\
\hline Brachionus falcatus & + & + & + & + & - & - & - \\
\hline Cephalodella spp. & - & + & - & - & - & + & - \\
\hline Collotheca spp. & + & + & + & + & + & - & + \\
\hline Conochilus coenobasis & + & + & + & + & + & + & - \\
\hline Conochilus unicornis & + & + & + & + & + & + & + \\
\hline Dicranophorus sp. & - & + & - & - & - & - & - \\
\hline Dipleuchnis propatula & - & + & - & - & - & - & - \\
\hline Encentrum sp. & - & - & - & + & - & - & - \\
\hline Epiphanes senta & - & - & + & - & - & - & - \\
\hline Euchlanis dilatata & - & + & - & - & - & - & - \\
\hline Euchlanis incisa f. mucronata & - & + & - & - & - & - & - \\
\hline Euchlanis sp. & + & - & - & - & - & - & - \\
\hline Filinia longiseta & + & + & + & - & + & - & - \\
\hline Filinia opoliensis & - & + & - & - & - & - & - \\
\hline Filinia terminalis & + & + & - & + & + & + & + \\
\hline Gastropus stylifer & - & - & - & + & - & - & - \\
\hline Hexarthra intermedia & + & + & + & + & + & + & + \\
\hline Horaëlla spp. & + & + & - & + & + & - & - \\
\hline Keratella americana & + & + & + & + & + & + & - \\
\hline Keratella cochlearis & + & + & + & + & + & + & + \\
\hline Keratella cochlearis brevispina & - & - & - & - & - & - & + \\
\hline Keratella cochlearis hispida & - & - & - & - & + & - & - \\
\hline Keratella lenzi & - & - & - & + & + & - & - \\
\hline Keratella tropica & + & - & + & + & - & - & - \\
\hline Lecane aculeata & + & - & - & - & - & - & - \\
\hline Lecane bulla & - & + & - & - & - & - & + \\
\hline Lecane closterocerca & - & - & - & - & - & - & + \\
\hline
\end{tabular}


TABLE 2 (Continued)

\begin{tabular}{|c|c|c|c|c|c|c|c|}
\hline \multirow[b]{2}{*}{ Species } & \multicolumn{7}{|c|}{ Reservoirs } \\
\hline & 目 & 㞼 & 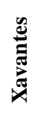 & 窇 & 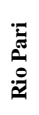 & שָ & 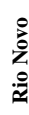 \\
\hline Lecane latissima & - & + & - & - & - & - & - \\
\hline Lecane ludwigi & - & - & - & + & - & - & - \\
\hline Lecane lunaris & + & + & - & + & - & - & - \\
\hline Lecane lunaris perplexa & - & - & - & + & - & - & - \\
\hline Lecane nana & - & + & - & - & - & + & - \\
\hline Lecane obtusa & + & - & - & - & - & - & - \\
\hline Lecane ruttneri & - & + & - & - & - & - & - \\
\hline Lecane spp. & + & - & - & + & - & - & - \\
\hline Lecane stenroosi & - & + & - & - & - & + & - \\
\hline Lecane stichaea & - & + & - & - & - & - & - \\
\hline Lepadella acuminata & - & - & - & + & - & - & - \\
\hline Macrochaetus sericus & - & - & - & - & - & - & + \\
\hline Monommata sp. & - & - & - & + & - & - & - \\
\hline Mytilina bisulcata & - & + & - & + & - & - & - \\
\hline Mytilina mucronata & - & + & - & - & - & - & - \\
\hline Notholca verae & - & - & - & - & - & - & + \\
\hline Notommata sp. & - & + & - & - & - & - & - \\
\hline Platyias quadricornis & - & + & - & - & - & - & - \\
\hline Pleosoma truncatum & - & - & + & + & - & + & - \\
\hline Polyarthra dolichoptera & + & - & - & - & - & - & + \\
\hline Polyarthra remata & - & - & - & - & - & - & + \\
\hline Polyarthra vulgaris & + & + & + & + & + & + & + \\
\hline Pompholyx triloba & - & - & - & + & + & + & - \\
\hline Ptygura libera & - & - & + & - & - & - & - \\
\hline Squatinella longispinata & - & + & - & - & - & - & - \\
\hline Synchaeta pectinata & + & + & - & - & - & - & + \\
\hline Synchaeta spp. & + & - & - & - & - & + & - \\
\hline Synchaeta stylata & + & + & + & + & + & + & + \\
\hline Testudinella mucronata hauerensis & - & - & - & - & + & - & - \\
\hline Testudinella patina & - & + & - & - & - & - & - \\
\hline Trichocerca capucina & + & + & + & + & - & + & - \\
\hline Trichocerca chattoni & + & - & - & + & - & + & - \\
\hline Trichocerca cylindrica & + & + & - & - & + & - & + \\
\hline Trichocerca elongata & - & - & + & - & - & - & - \\
\hline Trichocerca pusilla & - & - & - & + & - & - & + \\
\hline Trichocerca similis & + & - & + & - & + & + & - \\
\hline Trichocerca spp. & - & + & - & - & + & - & - \\
\hline Trichocerca stylata & + & + & + & - & + & + & + \\
\hline Trichotria tectratis & - & + & - & - & - & - & - \\
\hline Bdelloidea & + & + & - & + & - & + & - \\
\hline
\end{tabular}


TABLE 3

Species composition of Copepoda in the zooplankton communities of seven reservoirs at Parapanema River, along the year 1979.

\begin{tabular}{|c|c|c|c|c|c|c|c|}
\hline \multirow[b]{2}{*}{ Species } & \multicolumn{7}{|c|}{ Reservoirs } \\
\hline & & 光 & 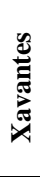 & 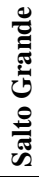 & 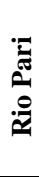 & 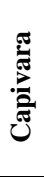 & 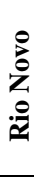 \\
\hline Argyrodiaptomus furcatus & + & + & + & + & - & + & - \\
\hline Notodiaptomus conifer & + & + & + & + & + & + & - \\
\hline Mesocyclops brasilianus & + & + & + & + & + & + & + \\
\hline Mesocyclops longisetus & - & + & - & - & - & - & - \\
\hline Paracyclops fimbriatus & + & + & + & + & - & - & + \\
\hline Thermocyclops decipiens & + & + & + & + & + & + & + \\
\hline Thermocyclops minutus & + & + & + & + & - & + & + \\
\hline
\end{tabular}

Generally, the highest diversity index was found in the same place as the highest species richness. However, the converse was not true, since the reservoirs with smallest diversity index did not coincide with the smallest richness (Table 5). Concerning the species richness of each zooplankton group, the highest number of Rotifera species, 40, was recorded in Piraju Reservoir; while 19 species of Cladocera were found in Piraju and Salto Grande reservoirs and 7 species of Copepoda at Piraju Reservoir (Table 6).

The constant rotifer species, according to the criteria used, were: Keratella cochlearis (70\%), Polyarthra vulgaris (70\%), Keratella americana (67\%), Collotheca spp. (63\%), Conochilus unicornis $(59 \%)$, Conochilus coenobasis $(52 \%)$ and Filinia terminalis (52\%). Among microcrustaceans, the following were constant: Notodiaptomus conifer (85\%), Thermocyclops decipiens (85\%), Ceriodaphnia cornuta cornuta (81\%), Daphnia gessneri (81\%), Ceriodaphnia cornuta rigaudi (78\%), Bosmina hagmanni (78\%), Diaphanosoma birgei (67\%), Mesocyclops brasilianus (59\%), Moina minuta (59\%), Diaphanosoma fluviatile (56\%) and Thermocyclops minutus (56\%). A large number of species were considered rare, comprising 43 species of Rotifera, 10 of Cladocera and 1 species of Copepoda (Mesocyclops longisetus). These were present on two sampling dates, at the most. The most constant zooplankton species in each reservoir in each group of organisms are shown in Table 7.

Comparisons of species composition by the Sørensen Index, among the various reservoirs, revealed that the most similar ones were: in $\mathrm{Fe}$ bruary, Jurumirim and Capivara (67\%), Capivara and Xavantes (62\%), Salto Grande and Xavantes (62\%); in May: Jurumirim and Capivara (68\%), Jurumirim and Salto Grande (63\%), Jurumirim and Rio Pari (60\%); in August, Jurumirim and Capivara $(65 \%)$; in November: Jurumirim and Xavantes (81\%), Jurumirim and Piraju (69\%), Jurumirim and Rio Pari (62\%). Taking the four sampling periods together, the similarity among reservoirs regarding zooplankton species composition was low in most cases. Rio Novo zooplankton was the least similar, compared to the others.

\section{Relative abundance and density of zooplankton}

The relative abundance of the zooplankton species in each reservoir studied was quite variable. It varied from $2 \%$ to $96 \%$, among Rotifera; from $3 \%$ to $97 \%$ for Cladocera; and from $0.1 \%$ to $52 \%$ for Copepoda. In most samples taken, Rotifera were the most abundant group, representing more than $50 \%$ of the total (17 samples). 
TABLE 4

Species composition of Cladocera in the zooplankton communities of seven reservoirs at Parapanema River, along the year 1979.

\begin{tabular}{|c|c|c|c|c|c|c|c|}
\hline \multirow[b]{2}{*}{ Species } & \multicolumn{7}{|c|}{ Reservoirs } \\
\hline & 罵 & 可 & 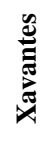 & 兑 & 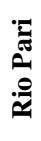 & : & \begin{tabular}{l}
8 \\
0 \\
$z$ \\
\hdashline \\
\hdashline
\end{tabular} \\
\hline Acroperus arpae & - & - & - & + & - & - & - \\
\hline Alona davidi & - & + & - & - & - & - & - \\
\hline Alona gutata gutata & - & - & - & + & - & - & - \\
\hline Alona eximia & - & + & - & + & - & - & - \\
\hline Alona monacantha & - & - & - & + & - & - & - \\
\hline Alona retangula pulchra & - & + & - & + & - & - & - \\
\hline Alona retangula retangula & - & + & + & + & - & - & + \\
\hline Bosmina hagmanni & + & + & + & + & + & + & + \\
\hline Bosmina longirostris & + & + & + & + & - & - & + \\
\hline Bosminopsis deitersi & - & + & + & + & - & - & + \\
\hline Ceriodaphnia cornuta cornuta & + & + & + & + & + & + & + \\
\hline Ceriodaphnia cornuta rigaudi & + & + & + & + & + & + & + \\
\hline Ceriodaphnia silvestrii & + & + & + & + & + & - & - \\
\hline Daphnia gessneri & + & + & + & + & + & + & + \\
\hline Diaphanosoma spinulosum & - & - & - & - & - & + & - \\
\hline Diaphanosoma birgei & + & + & + & + & + & + & - \\
\hline Diaphanosoma fluviatile & + & + & + & + & - & + & - \\
\hline Eurialona orientalis & - & - & - & + & - & - & - \\
\hline Eurialona brasiliensis & - & + & + & - & - & - & - \\
\hline Ilyocryptus spinifer & - & + & - & + & - & - & - \\
\hline Leydigia acanthocercoides & - & + & - & - & - & - & - \\
\hline Leydigiopsis sp. & - & - & - & + & - & - & - \\
\hline Macrothrix spinosa & - & + & - & - & - & - & - \\
\hline Moina minuta & + & + & + & + & + & + & + \\
\hline Simocephalus serrulatus & + & + & + & - & + & - & - \\
\hline
\end{tabular}


Cladocera was the most abundant group in the Xavantes in August and in Rio Pari in May. Copepoda, Cyclopoida were more abundant than other groups, particularly as nauplii, at Jurumirim in May, in Xavantes in November, in Capivara in February and in Rio Novo in February. Copepoda, Calanoida was the dominant group only in Xavantes Reservoir, in February.

The most abundant zooplankton species in each reservoir and each sampling period are shown in Table 8.

The highest density of organisms, $2.33 \times 10^{5}$ org. $\mathrm{m}^{-3}$, occurred in the Rio Pari Reservoir in November, and the lowest, $3.35 \times 10^{2}$ org. $\mathrm{m}^{-3}$, in Piraju Reservoir in May. High density, $1.49 \times 10^{5}$ org. $\mathrm{m}^{-3}$, was also observed in Rio Novo Reservoir in May. Detailed changes in the main populations are presented separately for each reservoir, as follows:

\section{Jurumirim Reservoir}

In this reservoir high abundance of rotifers occurred on three of the four sampling dates: February, August and November (Fig. 2). In May,
Copepoda, mainly represented by Cyclopoida nauplii, increased, reaching abundances similar to those of Rotifera.

Considering the four sampling periods, different species alternated in dominance. In August Synchaeta sp. represented more than $50 \%$ of total individuals present. Regarding numerical densities, in Copepoda, Cyclopoida, T. decipiens occurred at higher densities than $T$. minutus in all sampling periods, while in Calanoida, $N$. conifer was at all times denser than $A$. furcatus. The species Ceriodaphnia cornuta and its varieties occurred in higher abundances than other species of Cladocera, except in August when B. hagmanni and $D$. fluviatile were dominant. Regarding the phytoplankton, Baccilariophyceae were abundant in February and August, when highest densities of zooplankton occurred. Cyanophyceae were abundant in May and Chlorophyceae in December (Table 9). Principal component analysis shows that the abundances of Cyanophyceae were strongly and positively correlated with the abundance of Copepoda, Cyclopoida.
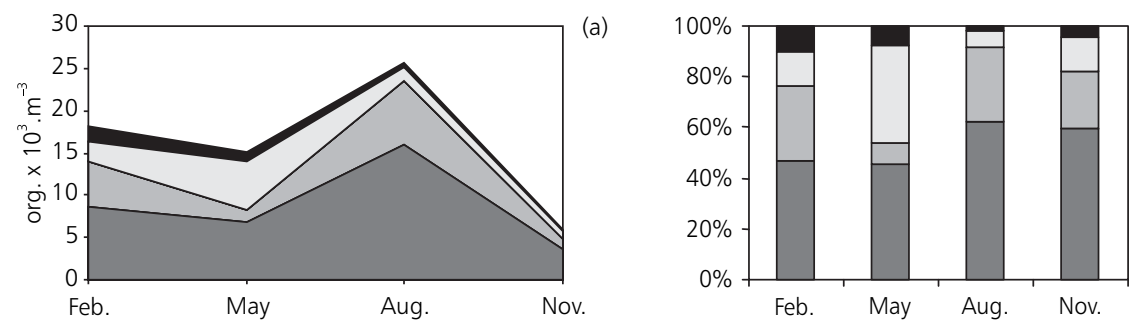

(b)

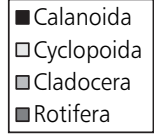

Fig. 2 - Changes in absolute densities (a) and relative abundance (b) of main zooplankton groups in Jurumirim Reservoir, during 1979.
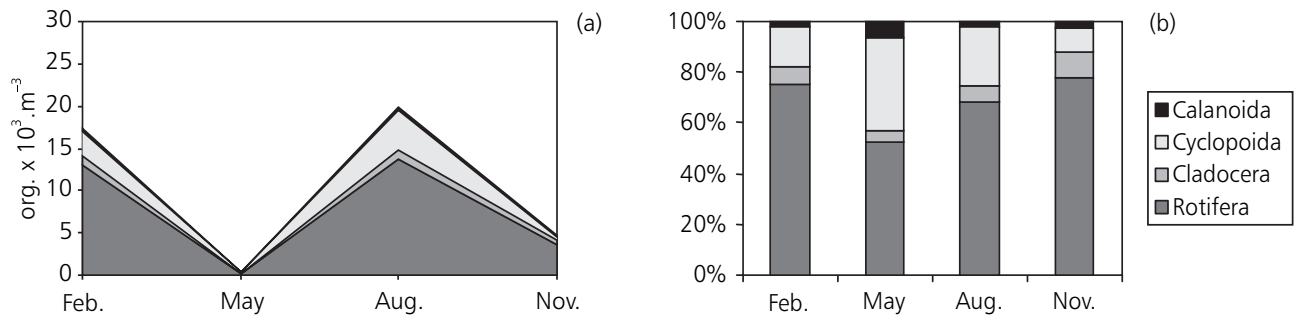

Fig. 3 - Changes in absolute densities (a) and relative abundance (b) of the zooplankton groups in Piraju Reservoir, during 1979. 
TABLE 5

Number of species (NS) and zooplankton diversity index (SWI) in seven reservoirs of Paranapanema River, during four periods sampled in 1979.

\begin{tabular}{|c|c|c|c|c|c|c|c|c|}
\hline \multirow{3}{*}{ Reservoir } & \multicolumn{8}{|c|}{ Period } \\
\hline & \multicolumn{2}{|c|}{ Frebuary } & \multicolumn{2}{|c|}{ May } & \multicolumn{2}{|c|}{ August } & \multicolumn{2}{|c|}{ November } \\
\hline & NS & SWI & NS & SWI & NS & SWI & NS & SWI \\
\hline Jurumirim & 32 & 2.7 & 32 & 2.5 & 24 & 1.9 & 25 & 2.5 \\
\hline Piraju & 42 & 3.0 & 26 & 2.7 & 26 & 2.2 & 28 & 2.5 \\
\hline Xavantes & 21 & 2.4 & 22 & 2.3 & 17 & 1.5 & 26 & 2.8 \\
\hline Salto Grande & 21 & 2.6 & 24 & 2.2 & 17 & 2.4 & 45 & 3.0 \\
\hline Rio Pari & 19 & 2.3 & 19 & 2.2 & 18 & 1.9 & 21 & 2.0 \\
\hline Capivara & 20 & 2.2 & 25 & 2.5 & 17 & 2.2 & - & - \\
\hline Rio Novo & 12 & 1.6 & 20 & 1.9 & 15 & 1.5 & 17 & 2.0 \\
\hline
\end{tabular}

NS - Total number of species, including Rotifera, Cladocera and Copepoda; SWI - Index of Shannon-Winer (bits) on natural logarithms.

TABLE 6

Number of species of Rotifera, Cladocera and Copepoda in seven reservoirs of Paranapanema River during in the year of 1979.

\begin{tabular}{|l|c|c|c|}
\hline \multirow{2}{*}{ Reservoir } & \multicolumn{3}{c|}{ Group } \\
\cline { 2 - 4 } & Rotifera & Cladocera & Copepoda \\
\hline Jurumirim & 31 & 10 & 6 \\
\hline Piraju & 40 & 19 & 7 \\
\hline Xavantes & 23 & 13 & 6 \\
\hline Salto Grande & 34 & 19 & 6 \\
\hline Rio Pari & 22 & 8 & 3 \\
\hline Capivara & 22 & 8 & 5 \\
\hline Rio Novo & 18 & 7 & 4 \\
\hline
\end{tabular}

\section{Piraju Reservoir}

In Piraju Reservoir, Rotifera was the dominant group in all sampting periods (Fig. 3). In May, Copepoda, represented mainly by Cyclopoida, increased in abundance, but never reached dominance. In this reservoir, there was no single constant dominant species throughout the year. Different species alternated in dominance in each period.

There was a great abundance of $P$. vulgaris in February, T. decipiens in May, S. pectinata, T. minutus and T. decipiens in August and $K$. cochlearis in November. Baccilariophyceae was the dominant phytoplankton group in all four sampling periods. Strong correlation existed between the abundances of particular groups of algae and those of zooplankton: Dinophyceae was correlated with Cladocera; Euglenophyceae with Copepoda, Calanoida and Chlorophyceae with Rotifera.

\section{Salto Grande Reservoir}

There was a dominance of Rotifera over the other groups, during all four periods analysed (Fig. 4). Many species were abundant, without any particular one dominating, throughout the study. 
The highest density of organisms was registered in November, probably associated with food quality, since at that time there was a predominance of Chlorophyceae and a large amount of suspended matter in the water column.

Dinophyceae were dominant in February and Chlorophyceae in the other three periods. No clear or significative correlation was found between the abundances of the groups of phytoplankton and zooplankton in this reservoir.

\section{Xavantes Reservoir}

Copepoda were most abundant in February and November in the Xavantes Reservoir. Rotifera was the most abundant group in May and Cladocera in August (Fig. 5). There were no dominant species, but several were abundant. Regarding the phytoplankton, Chlorophyceae and Cyanophyceae were the most representative groups during the four periods studied. The highest abundances of Copepoda occurred in February and November, due to a large number of nauplii in those periods, coinciding with a predominance of Cyanophyceae in the phytoplankton. Cyanophyceae were dominant in May and Chlorophyceae in August. The latter month was the period with the greatest relative abundance of Cladocera. A weak correlation was found between the abundances of Cyanophyceae and Copepoda, and a significant correlation between Chlorophyceae and Cladocera.

\section{Rio Pari Reservoir}

Rotifera was the most abundant group of organisms in Rio Pari Reservoir, in February, August and November, whereas Cladocera was most abundant in May (Fig. 6). No dominant species were observed but many species were abundant throughout the year. High densities of zooplankton were found in all periods studied. Regarding the phytoplankton, Euglenophyceae were the most abundant group in February and Chrysophyceae were dominant in the other periods.
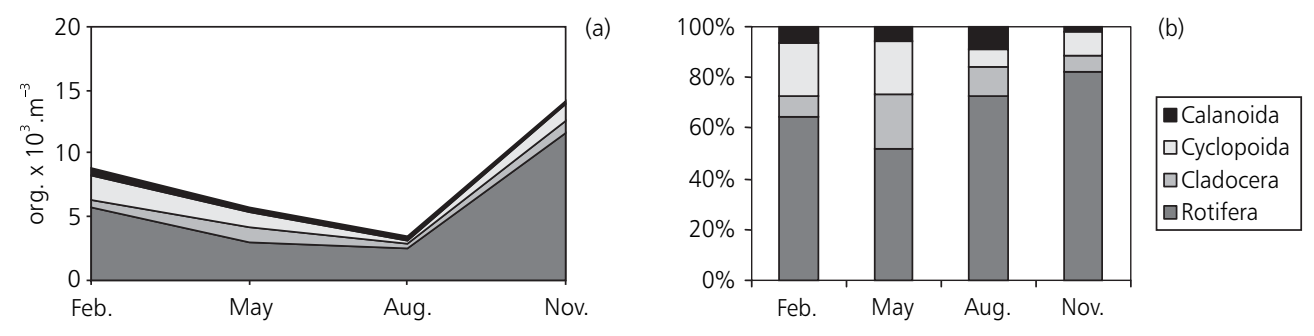

Fig. 4 - Changes in absolute densities (a) and relative abundance (b) of zooplankton groups in Salto Grande Reservoir, during 1979.
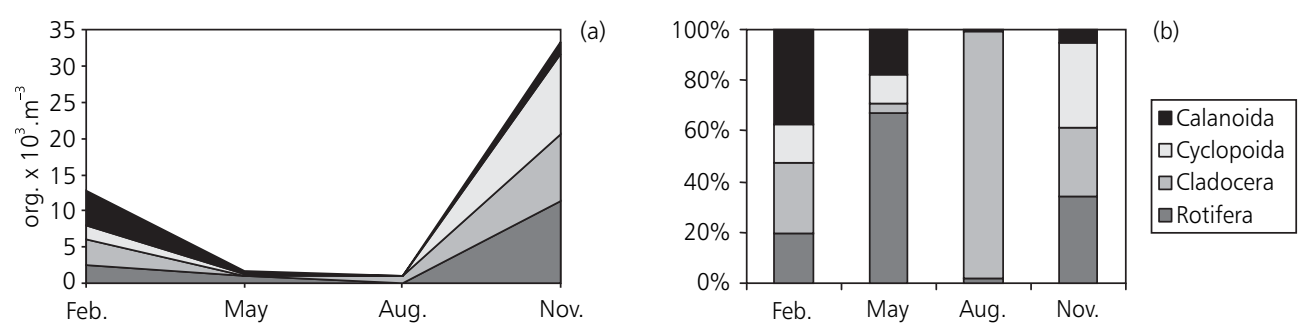

Fig. 5 - Changes in absolute densities (a) and relative abundance (b) of zooplankton groups in Xavantes Reservoir, during 1979. 

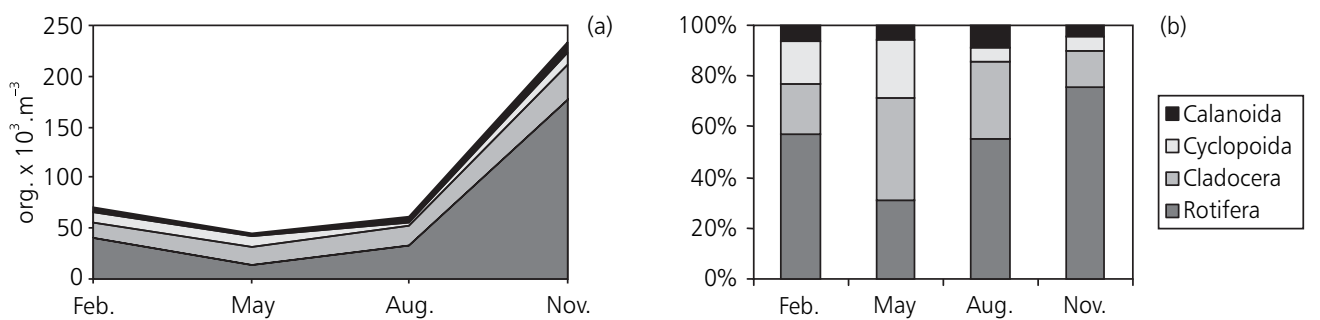

Fig. 6 - Changes in absolute densities (a) and relative abundance (b) of zooplankton groups in Rio Pari Reservoir, during 1979

TABLE 7

Zooplankton taxa most frequent in each reservoir during 1979.

\begin{tabular}{|c|c|c|c|}
\hline \multirow{2}{*}{ Reservoir } & \multicolumn{3}{|c|}{ Group } \\
\hline & Rotifera & Cladocera & Copepoda \\
\hline Jurumirim & $\begin{array}{l}\text { Colotheca } \text { sp. } \\
\text { Keratella americana }\end{array}$ & $\begin{array}{l}\text { Bosmina hagmanni } \\
\text { Ceriodaphnia c. cornuta } \\
\text { Ceriodaphnia c. rigaudi } \\
\text { Daphnia gessneri } \\
\text { Diaphanosoma fluviatile } \\
\text { Diaphanosoma birgei } \\
\text { Moina minuta }\end{array}$ & $\begin{array}{l}\text { Notodiaptomus conifer } \\
\text { Argyrodiaptomus furcatus } \\
\text { Thermocyclops decipiens } \\
\text { Thermocyclops minutus } \\
\text { Mesocyclops brasilianus }\end{array}$ \\
\hline Piraju & $\begin{array}{l}\text { Conochilus unicornis } \\
\text { Keratella americana } \\
\text { Keratella cochlearis } \\
\text { Bdelloidea }\end{array}$ & No species was constant & $\begin{array}{l}\text { Notodiaptomus conifer } \\
\text { Thermocyclops decipiens }\end{array}$ \\
\hline Xavantes & No species was constant & $\begin{array}{l}\text { Ceriodaphnia. } \text { C. cornuta } \\
\text { Diaphanosoma birgei }\end{array}$ & Notodiaptomus conifer \\
\hline Salto Grande & $\begin{array}{l}\text { Keratella americana } \\
\text { Bdelloidea }\end{array}$ & $\begin{array}{l}\text { Bosmina hagmanni } \\
\text { Daphnia gessneri }\end{array}$ & No species was constant \\
\hline Rio Pari & $\begin{array}{l}\text { Conochilus coenobasis } \\
\text { Conochilus unicornis } \\
\text { Hexarthra intermedia } \\
\text { Filinia terminalis } \\
\text { Trichocerca cylindrica }\end{array}$ & $\begin{array}{l}\text { Ceriodaphnia c. cornuta } \\
\text { Ceriodaphnia c. rigaudi } \\
\text { Ceriodaphnia silvestrii } \\
\text { Daphnia gessneri }\end{array}$ & $\begin{array}{l}\text { Notodiaptomus conifer } \\
\text { Thermocyclops decipiens }\end{array}$ \\
\hline Capivara & $\begin{array}{l}\text { Pleosoma truncatum } \\
\text { Trichocerca stylata }\end{array}$ & $\begin{array}{l}\text { Bosmina hagmanni } \\
\text { Ceriodaphnia c. cornuta } \\
\text { Ceriodaphnia c. rigaudi } \\
\text { Daphnia gessneri } \\
\text { Diaphanosoma birgei } \\
\text { Diaphanosoma fluviatile }\end{array}$ & Notodiaptomus conifer \\
\hline Rio Novo & $\begin{array}{l}\text { Colotheca } \text { sp. } \\
\text { Keratella cochlearis } \\
\text { Polyarthra vulgaris }\end{array}$ & No species was constant & Thermocyclops minutus \\
\hline
\end{tabular}


In November, a peak in zooplankton density was observed. At this time, the phytoplankton were dominated by Chrysophyceae. Principal component analysis indicated a significant correlation between the abundances of Cryptophyceae and Rotifera and a weak correlation between Cyanophyceae and Cladocera.

\section{Capivara Reservoir}

In Capivara Reservoir, a high abundance of Cyclopoida was observed in February and of Rotifera in May and August (Fig. 7). The relative abundance of Rotifera and Copepoda were very similar in the three periods analysed. Dominance was not observed.

The highest density of zooplankton occurred in August, mainly represented by Rotifera and Cyclopoida nauplii. Bacillariophyceae was dominant in August and February, whereas Cryptophyceae, were the most abundant algae in May. Cryptophyceae abundance was correlated with that of Rotifera and that of Baccilariophyceae with Copepoda, Calanoida.

\section{Rio Novo Reservoir}

In Rio Novo Reservoir, Cyclopoida was the most abundant group in February, and Rotifera in the other periods. Densities in May were also high (Fig. 8) followed by those in August, due to the high numbers of Rotifera. Species alternated dominance between periods. Thus, T. decipiens was dominant in February whereas Collotheca sp. was dominant in May. Little similarity was observed between the Cladocera species composition in this reservoir and in the others. Copepoda, Calanoida was absent most of the time. N. conifer occurred only in August, and at very low density.

Different phytoplanktonic groups alternated dominance in each period. Cryptophyceae were dominant in February; both Baccilariophyceae and Cyanophyceae in May and August, and Chlorophyceae in December. The relative abundances of Cyanophyceae and Baccilariophyceae were significantly correlated with Rotifera whereas Cryptophyceae and Euglenophyceae were correlated with Copepoda, Cyclopoida, as evidenced by principal component analysis.
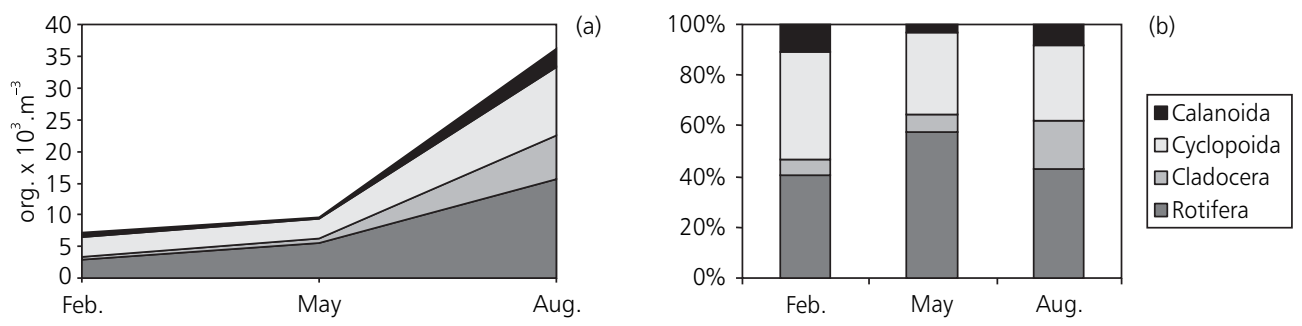

Fig. 7 - Changes in absolute densities (a) and relative abundance (b) of the zooplankton groups in Capivara Reservoir, during 1979.
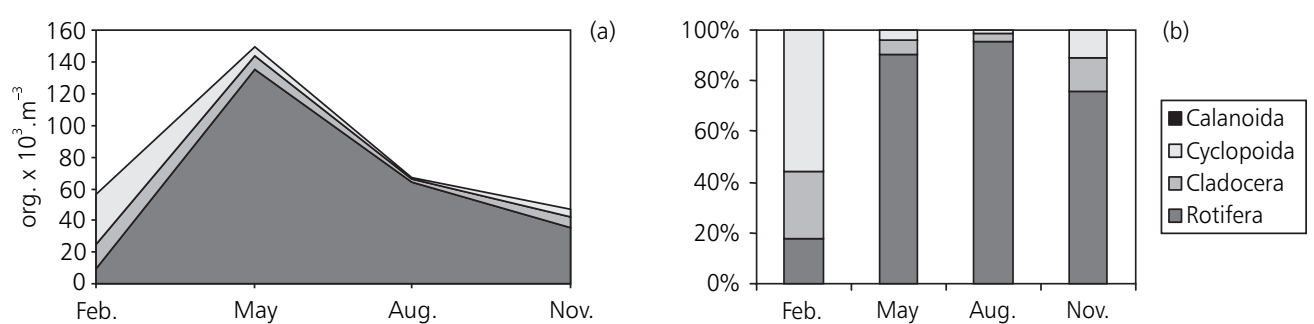

Fig. 8 - Changes in absolute densities (a) and relative abundance (b) of the zooplankton groups in Rio Novo Reservoir, during 1979. 
TABLE 8

Zooplankton taxa abundant in each reservoir during the four periods of sampling in 1979.

\begin{tabular}{|c|c|c|c|c|}
\hline \multirow{2}{*}{ Reservoir } & \multicolumn{4}{|c|}{ Period } \\
\hline & February & May & August & November \\
\hline Jurumirim & $\begin{array}{l}\text { Polyarthra vulgaris } \\
\text { Keratella americana }\end{array}$ & $\begin{array}{l}\text { Thermocyclops decipiens } \\
\text { Conochilus unicornis }\end{array}$ & Synchaeta sp. & $\begin{array}{l}\text { Keratella cochlearis } \\
\text { Keratella americana }\end{array}$ \\
\hline Piraju & $\begin{array}{l}\text { Polyarthra vulgaris } \\
\text { Thermocyclops decipiens }\end{array}$ & Thermocyclops decipiens & $\begin{array}{l}\text { Synchaeta pectinata } \\
\text { Keratella americana } \\
\text { Thermocyclops minutus } \\
\text { Thermocyclops decipiens }\end{array}$ & $\begin{array}{l}\text { Keratella cochlearis } \\
\text { Polyarthra vulgaris }\end{array}$ \\
\hline Xavantes & $\begin{array}{l}\text { Argyrodiaptomus } \\
\text { furcatus } \\
\text { Thermocyclops minutus } \\
\text { Ceriodaphnia cornuta } \\
\text { cornuta }\end{array}$ & $\begin{array}{l}\text { Keratella americana } \\
\text { Keratella cochlearis }\end{array}$ & $\begin{array}{l}\text { Bosmina longirostris } \\
\text { Daphnia gessneri }\end{array}$ & $\begin{array}{l}\text { Thermocyclops decipiens } \\
\text { Thermocyclops minutus } \\
\text { Keratella cochlearis }\end{array}$ \\
\hline $\begin{array}{l}\text { Salto } \\
\text { Grande }\end{array}$ & $\begin{array}{l}\text { Conochilus unicornis } \\
\text { Synchaeta stylata } \\
\text { Thermocyclops decipiens } \\
\text { Thermocyclops minutus }\end{array}$ & $\begin{array}{l}\text { Keratella americana } \\
\text { Daphnia gessneri } \\
\text { Thermocyclops decipiens }\end{array}$ & $\begin{array}{l}\text { Keratella cochlearis } \\
\text { Keratella americana }\end{array}$ & $\begin{array}{l}\text { Filinia terminalis } \\
\text { Trychocerca chattoni } \\
\text { Keratella americana } \\
\text { Keratella cochlearis } \\
\text { Keratella tropica }\end{array}$ \\
\hline Rio Pari & $\begin{array}{l}\text { Hexarthra intermedia } \\
\text { Ceriodaphnia cornuta } \\
\text { cornuta } \\
\text { Thermocyclops decipiens }\end{array}$ & $\begin{array}{l}\text { Daphnia gessneri } \\
\text { Thermocyclops decipiens } \\
\text { Hexarthra intermedia } \\
\text { Conochilus coenobasis }\end{array}$ & $\begin{array}{l}\text { Keratella cochlearis } \\
\text { Daphnia gessneri } \\
\text { Notodiaptomus conifer }\end{array}$ & $\begin{array}{l}\text { Trichocerca cylindrica } \\
\text { Keratella lenzi } \\
\text { Daphnia gessneri } \\
\text { Keratella cochlearis }\end{array}$ \\
\hline Capivara & $\begin{array}{l}\text { Thermocyclops decipiens } \\
\text { Trichocerca similis }\end{array}$ & Thermocyclops decipiens & $\begin{array}{l}\text { Mesocyclops brasilianus } \\
\text { Trichocerca stylata } \\
\text { Synchaeta } \text { sp. }\end{array}$ & \\
\hline Rio Novo & $\begin{array}{l}\text { Thermocyclops decipiens } \\
\text { Bosminopsis deitersi }\end{array}$ & $\begin{array}{l}\text { Colotheca } \text { sp. } \\
\text { Synchaeta pectinata } \\
\text { Polyarthra remata }\end{array}$ & $\begin{array}{l}\text { Filinia terminalis } \\
\text { Polyarthra vulgaris } \\
\text { Colotheca } \mathrm{sp} .\end{array}$ & $\begin{array}{l}\text { Colotheca } \text { sp. } \\
\text { Filinia terminalis } \\
\text { Moina minuta }\end{array}$ \\
\hline
\end{tabular}

\section{DISCUSSION}

The main groups composing zooplankton communities are the protozoans, rotifers and crustaceans, particularly copepods and cladocerans (Hutchinson, 1967), although freshwater zooplankton, especially in tropical regions, may contain a diverse set of taxonomical categories (Wetzel, 1983; Dumont et al., 1994).

In the Paranapanema reservoirs, besides planktonic rotifers, cladocerans, copepods and protozoans, some meroplanktonic groups were also observed at low density and frequency, such as: the rhizopods Difflugia sp., Arcella discoides, Centropixis aculeata, Acari, Bryozoa, Diptera (Chaoboridae and Chironomidae), Conchostraca, Nematoda, Oligochaeta, Ostracoda, Plecoptera, Trichoptera and Turbellaria.
However, they were not considered in the present study, due to taxonomical difficulties.

In the samples taken from the seven reservoirs of the Paranapanema River Basin for this study, a total of 108 species and subspecies were identified, the largest fraction belonging to Rotifera.

Jurumirim Reservoir, an oligotrophic environment, has been the focus of a number of studies of the zooplankton community. Recently, Henry $\&$ Nogueira (1999) reported the occurrence of 82 species of Rotifera, 17 species of Cladocera, 10 species of Protozoa and 8 of Copepoda.

The present inventory provides evidence that there were more species of Rotifera and Cladocera in the zooplankton community of Salto Grande and Piraju reservoirs in 1979, than were recently recorded by Henry \& Nogueira (1999). 
TABLE 9

Relative abundance of phytoplankton groups occurring in Parapanema reservoirs during the four periods of sampling in 1979. The sample for Capivara Reservoir in November was lost.

\begin{tabular}{|c|c|c|c|c|c|}
\hline \multirow{2}{*}{ Reservoir } & \multirow{2}{*}{ Group } & \multicolumn{4}{|c|}{ Relative abundance $(\%)$} \\
\hline & & February & May & August & November \\
\hline Jurumirim & $\begin{array}{l}\text { Baccylariphyceae } \\
\text { Cyanophyceae } \\
\text { Chlorophyceae } \\
\text { Chrysophyceae } \\
\text { Xanthophyceae } \\
\text { Dinophyceae }\end{array}$ & $\begin{array}{c}51 \\
34 \\
10 \\
3 \\
2 \\
-\end{array}$ & $\begin{array}{c}23 \\
59 \\
12 \\
6 \\
- \\
-\end{array}$ & $\begin{array}{c}43 \\
26 \\
25 \\
3 \\
3 \\
-\end{array}$ & $\begin{array}{c}20 \\
30 \\
37 \\
11 \\
- \\
<1\end{array}$ \\
\hline Piraju & $\begin{array}{l}\text { Bacillariophyceae } \\
\text { Cyanophyceae } \\
\text { Chlorophyceae } \\
\text { Chrysophyceae } \\
\text { Dinophyceae } \\
\text { Euglenophyceae }\end{array}$ & $\begin{array}{c}66 \\
14 \\
19 \\
- \\
<1 \\
-\end{array}$ & $\begin{array}{c}63 \\
28 \\
8 \\
<1 \\
- \\
<1\end{array}$ & $\begin{array}{c}81 \\
7 \\
12 \\
- \\
- \\
-\end{array}$ & $\begin{array}{c}67 \\
8 \\
13 \\
12 \\
<1 \\
-\end{array}$ \\
\hline Salto Grande & $\begin{array}{l}\text { Bacillariophyceae } \\
\text { Cyanophyceae } \\
\text { Chlorophyceae } \\
\text { Chrysophyceae } \\
\text { Xanthophyceae } \\
\text { Dinophyceae } \\
\text { Euglenophyceae }\end{array}$ & $\begin{array}{l}- \\
8 \\
4 \\
- \\
- \\
84 \\
<1\end{array}$ & $\begin{array}{l}12 \\
10 \\
77 \\
- \\
- \\
- \\
-\end{array}$ & $\begin{array}{c}25 \\
4 \\
58 \\
12 \\
- \\
<1 \\
-\end{array}$ & $\begin{array}{c}24 \\
8 \\
55 \\
13 \\
<1 \\
<1 \\
-\end{array}$ \\
\hline Xavantes & $\begin{array}{l}\text { Bacillariophyceae } \\
\text { Cyanophyceae } \\
\text { Chlorophyceae } \\
\text { Chrysophyceae } \\
\text { Xanthophyceae } \\
\text { Dinophyceae }\end{array}$ & $\begin{array}{c}5 \\
65 \\
28 \\
- \\
1 \\
-\end{array}$ & $\begin{array}{l}11 \\
48 \\
41 \\
- \\
- \\
-\end{array}$ & $\begin{array}{l}15 \\
29 \\
47 \\
- \\
- \\
8\end{array}$ & $\begin{array}{c}14 \\
46 \\
34 \\
5 \\
- \\
3\end{array}$ \\
\hline Rio Pari & $\begin{array}{l}\text { Cyanophyceae } \\
\text { Chlorophyceae } \\
\text { Chrysophyceae } \\
\text { Xanthophyceae } \\
\text { Dinophyceae } \\
\text { Euglenophyceae } \\
\text { Cryptophyceae }\end{array}$ & $\begin{array}{c}- \\
24 \\
8 \\
5 \\
6 \\
43 \\
13\end{array}$ & $\begin{array}{l}15 \\
13 \\
56 \\
16 \\
- \\
- \\
-\end{array}$ & $\begin{array}{c}1 \\
1 \\
70 \\
5 \\
1 \\
- \\
21\end{array}$ & $\begin{array}{c}1 \\
3 \\
84 \\
- \\
2 \\
- \\
10\end{array}$ \\
\hline Capivara & $\begin{array}{l}\text { Bacillariophyceae } \\
\text { Cyanophyceae } \\
\text { Chlorophyceae } \\
\text { Cryptophyceae }\end{array}$ & $\begin{array}{c}56 \\
21 \\
23 \\
-\end{array}$ & $\begin{array}{c}30 \\
8 \\
27 \\
35\end{array}$ & $\begin{array}{c}46 \\
39 \\
15 \\
-\end{array}$ & - \\
\hline Rio Novo & $\begin{array}{l}\text { Bacillariophyceae } \\
\text { Cyanophyceae } \\
\text { Chlorophyceae } \\
\text { Chrysophyceae } \\
\text { Xanthophyceae } \\
\text { Dinophyceae } \\
\text { Euglenophyceae } \\
\text { Cryptophyceae }\end{array}$ & $\begin{array}{c}- \\
7 \\
24 \\
8 \\
- \\
6 \\
5 \\
51\end{array}$ & $\begin{array}{l}43 \\
32 \\
18 \\
- \\
- \\
7 \\
- \\
-\end{array}$ & $\begin{array}{l}32 \\
40 \\
17 \\
11 \\
- \\
- \\
- \\
-\end{array}$ & $\begin{array}{c}24 \\
18 \\
45 \\
8 \\
6 \\
- \\
- \\
-\end{array}$ \\
\hline
\end{tabular}


Many interacting physical, chemical and biological factors can influence zooplankton species composition, in both limnetic and littoral regions.

From the present results, it appears that the species richness and diversity were both at their highest when littoral species were present in the limnetic region, as occurred with species of the genus Lecane in Rotifera and with species belonging to the families Chydoridae and Macrothricidae, in Cladocera. This happened in periods of highest precipitation: February and November.

According to Rocha et al. (1995), Rotifera is the predominant group in most Brazilian reservoirs, with both the highest species richness and population densities in a variety of lakes, some of very contrasting trophic state. This fact may relate to some of their special characteristics, viz: less specialized feeding, high fecundity and frequent parthenogenetic reproduction, and a constellation of life traits that make them opportunist and typical r-strategists, favored in unstable and eutrophic environments (Allan, 1976; Matsumura-Tundisi et al., 1990). Also, the wide spectrum of food particles exploited by this group, which display the abylity to consume bacteria, algae and detritus of different sizes, allows quite distinct diets for the many species simultaneously present in a body of water, or even for the same species present in different environments (Starkweather, 1980). Bogdan et al. (1980) have shown experimentally, with using radioactive tracers, that different subspecies of Keratella cochlearis and various species of Polyarthra differed markedly regarding food particle utilization. It appears therefore that niche differentiation among related species has a strong influence on Rotifera assemblage composition and diversity, via competitive interactions. Excessive growth of Cyanophyceae algae usually inhibits the development of most herbivorous filter-feeders, by eliminating the small algae which form their basic diet (Edmondson, 1965). Additionally it has been suggested that toxic substances released by Cyanophyceae can directly limit the fertility of planktonic rotifers (Dumont, 1977).

In the present study, it was observed that Collotheca sp. occurred at a high frequency in Jurumirim, Rio Pari and Rio Novo reservoirs, and that in Rio Novo these species are present at high densities around the year. Also, fewer species were found in the Rotifera assemblage of Rio Novo than in those of Jurumirim and Rio Pari reservoirs, and this may represent diminished competition among species and thus explain the large Collotheca sp. populations in that water body. The rough phytoplankton analysis performed in this study, plus the results of the trophic state index for the reservoirs, do not provide enough information to explain the differences in Rotifera richness and abundance, among these reservoirs.

Considering all seven reservoirs and all four sampling periods, the Rotifera group was more abundant than Cladocera and Copepoda in $74 \%$ of the samples obtained. Eutrophication bioindicator species, such as Brachionus calyciflorus, rarely occurred. High densities of rotifers were nevertheless very common. It appears therefore, from the expected changes in community structure determined by eutrophication (Hellawell, 1978), that Paranapanema reservoir zooplankton are characterized by variation in the proportions of species, without any severe species replacement by tolerant forms. This observation agrees with the oligotrophic and mesotrophic status of the reservoirs, as indicated by recorded phosphorus and chlorophyll a concentrations.

Usually, Rotifera populations do not exhibit regular seasonal patterns of fluctuation in tropical lakes (Matsumura-Tundisi \& Tundisi, 1976; Matsumura-Tundisi et al., 1990). This has also and once more been found in the Paranapanema reservoirs, where different species of Rotifera assume dominance in different sampling periods and no species is dominant throughout the year.

Copepoda were dominant in only $19 \%$ of the samples, mainly in November and February. It constituted the second most abundant group in Piraju and Salto Grande reservoirs, in the four periods of study. According to Dussart \& Defaye (1995), most Calanoida are herbivorous, feeding on algae, whereas Cyclopoida tend to be more omnivorous, feeding additionally and even preferentially on other planktonic and also benthic microinvertebrates. Although the diet and the niche amplitude favour this group regarding resource allocation, the copepods have obligatory sexual reproduction and longer life cycles (Allan, 1976) resulting in a reduced number of generations compared to those of rotifers and cladocerans.

A large fraction of Copepoda populations in the reservoirs here studied consisted of Cyclopoida. Also in most reservoirs the number of copepodids and adults was very small, showing the reduced 
competitive ability of Copepoda in these environments.

Some Calanoida species appear to be better adapted to Cyanophyceae bloom conditions, as they are selective feeders and therefore less inhibited by these colonies than the large Cladocera, and are able to exploit conditions of high food abundance, but low quality (Haney, 1987). Among the species present in Paranapanema reservoirs, Notodiaptomus conifer was more frequent and abundant than Argyrodiaptomus furcatus. According to Espíndola (1994), N. conifer has the same natural diet as the other three congeneric species, feeding on Baccilariophyceae, Chlorophyceae and phytoflagellates. Only in Xavantes Reservoir, in the February sampling, Calanoida numbers surpassed those of Rotifera, Cyclopoida and Cladocera. At that time, A. furcatus was the most abundant species and the phytoplankton community were dominated by Cyanophyceae and Chlorophyceae. A. furcatus is considered an indicator of oligotrophic waters in Southern Brazil (MatsumuraTundisi \& Tundisi, 1976; Tundisi et al., 1999). In Rio Pari and Rio Novo reservoirs this species was absent all the time, reinforcing the mesotrophic and eutrophic condition of these two reservoirs. In a study in Jurumirim reservoir, Henry \& Nogueira (1999) have recently observed the dominance of a third species of Copepoda, Notodiaptomus iheringi, and low abundances for $N$. conifer and A. furcatus. Güntzel (2000), analysing the zooplankton composition in six reservoirs of Tietê River, São Paulo State, Brazil, also observed the replacement of Argyrodiaptomus furcatus by Notodiaptomus iheringi in Nova Avanhandava, Promissão and Jupiá reservoirs and considered this replacement to be a consequence of eutrophication, since those reservoirs have changed from oligotrophic to mesotrophic condition over the last two decades. It appears, from the present results, that eutrophication is already in progress in the Paranapanema reservoirs.

Among the seven species of Cyclopoida observed, Thermocyclops decipiens was the most frequent in all reservoirs, followed by Mesocyclops brasilianus and Thermocyclops minutus. Mesocyclops longisetus and Paracyclops fimbriatus were not frequent and exhibited low abundances.

According to Fernando et al. (1990), Thermocyclops species are generally considered herbivorous or sometimes carnivorous, while
Mesocyclops species are considered carnivorous or detritivorous. However, the extent to which a particular species is an obligate or facultative carnivore seems to vary. The feeding habit of Thermocyclops minutus has been called omnivorous, since this species feeds raptorially, hunting for large phytoplankton cells or eating colonies of Cyanophyceae and small zooplankton, such as the nauplii of other species of Copepoda (Matsumura-Tundisi et al., 1997). In Barra Bonita Reservoir (Tietê River, Brazil) besides Thermocyclops and Metacyclops, there are three species of Mesocyclops (M. longisetus, M. ogunnus and $M$. brasilianus). T. minutus and T. decipiens are usually found occurring together in several reservoirs (Matsumura-Tundisi et al., 1981; Reid \& Pinto-Coelho, 1994; Tundisi \& MatsumuraTundisi, 1994; Silva, 1998; Henry \& Nogueira, 1999; Güntzel, 2000). Rietzler (1995), studying the population dynamics and the life cycle of both species by rearing them in the laboratory, found that $T$. decipiens has competitive advantages over T. minutus. The latter species is usually found to be dominant in oligotrophic conditions, particularly lakes and reservoirs in preserved basins (Matsumura-Tundisi \& Tundisi, 1976; Sendacz et al., 1985; Güntzel, 2000; Sampaio \& López, in the press). On the other hand, Nogueira \& Panarelli (1997) observed vertical segregation between $T$. decipiens and T. minutus in the deep limnetic zone of Jurumirim Reservoir.

Thermocyclops decipiens has been considered a species typical of disturbed and nutrientenriched environments. Under mesotrophic conditions, T. minutus and T. decipiens alternate seasonally (Rocha et al., 1995, 1999). It is therefore quite interesting that, in $1979, T$. decipiens was the most frequent cyclopoid copepod in the Paranapanema reservoirs. The differences in observed abundance of T. minutus and T. decipiens among the Paranapanema reservoirs suggest that Rio Pari has a higher trophic index than the others, given the absence of T. minutus and the large abundance of T. decipiens. Moreover, in Rio Novo Reservoir, although the two species coexisted, $T$. decipiens was dominant, indicating a more eutrophic condition, which is also supported by the values of trophic index based on phosphorus and chlorophyll $a$ concentrations. In the remaining reservoirs, the two species alternate in dominance. The pattern of co-occurrence observed for the 
Thermocyclops congeneric association in Paranapanema reservoirs corroborates previous observations of a seasonal alternation of peak abundances, in oligotrophic conditions, and dominance or exclusive occurrence of $T$. decipiens under mesotrophic or eutrophic conditions.

Cladocera was the dominant group in $7 \%$ of the samples analysed and the second most abundant group in abundance in $41 \%$ of them. Predominance of Cladocera was observed only in Xavantes and Rio Pari reservoirs, in different periods.

Cladocerans have been claimed to be good indicators of trophic state in lentic ecosystems. In Europe, the size range of species has been used as an indicator of water quality. The existence of large species such as daphnids is an indicator of phytoplankton control by herbivory, whith is characteristic of better quality waters (Straškraba \& Tundisi, 2000). According to Gannon \& Stemberger (1978), species of Bosmina are good indicators of lake trophic state. Thus, Bosmina longirostris has been observed in eutrophic environments such as Barra Bonita Reservoir (Matsumura-Tundisi, 1999) and Billings Reservoir complex (Sendacz \& Kubo, 1999) both in São Paulo State, Brazil, while Güntzel (2000) observed that among the six reservoirs on Tietê River, Bosmina hagmanni was most abundant in the less eutrophic ones.

Along the cascade of reservoirs, two species of Cladocera were observed to achieve dominance, Bosmina longirostris being abundant in August and Ceriodaphnia cornuta at other times of the year. The predominance of small cladocerans (Bosmina and Ceriodaphnia) in more eutrophic waters is generally related to the interference of filamentous or toxic bluegreen algae, which dominate the phytoplankton under eutrophic conditions. Filterfeeding mechanisms of large cladocerans such as Daphnia and Diaphanosoma may be damaged, as a consequence of the blocking of filtering apparatus by filaments or by the sticky mucilage of large Cyanophyceae colonies (Lampert, 1987). The size structure of zooplankton may also be changed by selective predation of certain fishes on the large forms (Brooks \& Dodson, 1965). The dominance of small species observed in the cascade of Paranapanema reservoirs is probably related to interference in the feeding, given that Cyanophyceae were abundant at most times of the year. In Jurumirim reservoir, Cladocera densities were low when Cyanophyceae algae were abundant but peaks occurred when Baccilariophyceae were abundant.
Species of Daphnidae predominated in Rio Pari reservoir, represented mainly by $C$. cornuta and D. gessneri. Bosminopsis deitersi and Moina minuta alternately dominated, Rio Novo reservoir. C. cornuta and D. gessneri are euryokous species, physiologically and morphologically adapted to living all along the oligotrophy-hypereutrophy gradient. They are therefore not good bioindicators. Bosminopsis deitersi and Moina minuta, on the other hand, seem to be restricted to one end of the range, being dominant in oligotrophic, although also occurring in mesotrophic, conditions.

Recently, Henry \& Nogueira (1999) reported the dominance of Diaphanosoma birgei in Jurumirim Reservoir, which suggests that a change in zooplankton species composition has occurred in the last twenty years, due to the advance of eutrophication.

Cladoceran species richness was highest in the Piraju and Salto Grande Reservoir, but even these densities were relatively low. Sampaio (1989) has found that out of 23 reservoirs in São Paulo State, the highest Cladocera species richness occurred in those two reservoirs.

The results of this study suggest that Piraju and Salto Grande had highest species diversity in both Rotifera and Cladocera. Possibly the age of the reservoirs is a relevant factor. These are the oldest reservoirs on Paranapanema river. Piraju was closed in 1962 and Salto Grande in 1958. The others date from the late seventies onwards. These two reservoirs therefore had a longer time to be colonized and probably had already reached a stable community, with most available niches occupied.

Aknowledgments - The authores thank FAPESP and CNPq for financial support and CESP, the São Paulo State Energy Company for infra-structure provided during the field work.

\section{REFERENCES}

ABEL, P. D., 1989, Water pollution biology. Ellis Horwood Limited Publishers, Halsted Press: a division of John Wiley \& Sons, Chichester, 232p.

ALLAN, J. D., 1976, Life history patterns in zooplankton. Am. Nat., 110: 165-176.

BAYS, J. S. \& CRISMAN, T. L., 1983, Zooplankton and trophic state relationships in Florida lakes. Can. J. Fish. Aquat. Sci., 140: 1813-1819.

BOGDAN, K. G., GILBERT, J. J. \& STARKWEATHER, P. L., 1980, In situ clearance rates of planktonic rotifers. Hydrobiologia, 73: 73-77.

BROOKS, J. L. \& DODSON, S. I., 1965, Predation, body size, and composition of plankton. Science, 150: 28-35. 
CAMPBELL, J. M. \& HAASE, B. L., 1981, Availability of suitable phytoplanktonic food for zooplankton in an icecovered lake. Hydrobiologia, 79: 113-119.

DRENNER, R. W., De NOYELLES Jr., F. \& KETTLE, D., 1982, Selective impact of filter-feeding gizzard shad on zooplankton community structure. Limnol. Oceanogr., 27(5): $965-968$.

DUMMONT, H. J., 1977, Biotic factors in population dynamics of rotifers. Arch. Hydrobiol. Beih., 8: 98-122.

DUMMONT, H. J., ROCHA, O. \& TUNDISI, J. G., 1994, The impact of predation in structuring zooplankton communities with emphasis on some lakes in Brazil. Proceedings of Anales del Seminario Internacional del Água. Mazatlán, México, pp. 11-43.

DUSSART, B. H. \& DEFAYE, D., 1995, Copepoda: introduction to the Copepoda. SPB Academic Publishing, The Hague, 277p.

EDMONDSON, W. T., 1965, Reproductive rate of planktonic rotifers as related to food and temperature in nature. Ecol. Monogr., 35: 61-111.

EGBORGE, A. B. M., 1994, Salinity and the distribution of rotifers in the Lagos Harbour-Badagry Creek system, Nigeria. Hydrobiologia, 272: 95-104.

ESPÍNDOLA, E. L. G., 1994, Dinâmica da associação congenérica das espécies de Notodiaptomus (Copepoda, Calanoida) no reservatório de Barra Bonita, São Paulo. Tese de Doutorado, Escola de Engenharia de São Carlos, Universidade de São Paulo, 363p.

FERNANDO, C. H., TUDORANCEA, C. \& MENGESTOU, S., 1990, Invertebrate zooplankton predator composition and diversity in tropical lentic waters. Hydrobiologia, 198: 13-31.

FULTON, R. S. III \& PAERL, H. W., 1987, Effects of colonial morphology on zooplankton utilization of algal resources during blue-green algal (Microcystis aeruginosa) blooms. Limnol. Oceanogr., 32(3): 634-644.

GANNON, J. E. \& STEMBERGER, R. S., 1978, Zooplankton (especially crustaceans and rotifers) as indicators of water quality. Trans Amer. Micros. Soc., 97(1): 16-35.

GOMES, A. S., 1989, Distribuição espacial dos moluscos bivalves na região da plataforma continental de Cabo Frio, Praia de Maçambaba, Estado do Rio de Janeiro, Brasil. Dissertação de Mestrado, Universidade Federal do Rio de Janeiro, 122p.

GÜNTZEL, A., 2000, Variações espaço-temporais da comunidade zooplanctônica nos reservatórios do médio e baixo rio Tietê/Paraná, SP. Tese de Doutorado, Universidade Federal de São Carlos, 445p.

HANEY, J. F., 1987, Field studies on zooplankton-cyanobacteria interactions. NZ J. Mar. Freshwater Res., 21: 467-475.

HENRY, R., 1999, Heat budgets, thermal structure and dissolved oxyigen in Brasilian reservoirs, pp. 125-151. In: J. G. Tundisi \& M. Straškraba (eds.), Theoretical reservoir ecology and its applications. International Institute of Ecology, Brazilian Academy of Sciences and Backhuys Publishers, São Carlos, 585p.
HENRY, R. \& NOGUEIRA, M. G., 1999, A represa de Jurumirim (São Paulo): primeira síntese sobre o conhecimento limnológico, pp. 651-686. In: R. Henry (ed.), Ecologia de reservatórios: estrutura, função e aspectos sociais. FUNDIBIO/FAPESP, Botucatu, 799p.

HILLBRICHT-ILKOWSKA, A., 1972, Interlevel energy transfer efficiency in planktonic food chains. Proceedings of International Biological Programme, Section PH. December 13, Reading England.

HUTCHINSON, G. E., 1967, A Treatise on Limnology. Introduction to lake biology and the limnoplankton. John Wiley \& Sons, Inc., New York, 2o vol., 1115p.

ILEC, 1999, International Lake Environment Committee Foundation. World lake database, Index of world lakes. Available (1999) at URLs: http://www.ilec.or.jp/database/ sam/dssam047.html, http://www.ilec.or.jp/database/sam/ dssam048.html, http://www.ilec.or.jp/database/sam/dssam 049.html, Consulted on 3/2/01.

INFANTE, A., 1982, Annual variations in abundance of zooplankton in Lake Valencia (Venezuela). Arch. Hydrobiol., 95(2): 194-202.

LAMPERT, W., 1987, Laboratory studies on zooplanktoncyanobacteria interactions. NZ J. Mar. Freshwater Res., 21: 483-490.

LOBO, E. \& LEIGHTON, G., 1986, Estructuras comunitarias de las fitocenosis planctonicas de los sistemas de desembocaduras de ríos y esteros de la zona central de Chile. Rev. Biol. Mar., 22(1): 1-29.

MATSUMURA-TUNDISI, T., 1999, Diversidade de zooplâncton em represas do Brasil, pp. 39-54. In: R. Henry (ed.), Ecologia de reservatórios: estrutura, função e aspectos sociais. FUNDIBIO/FAPESP, Botucatu, 799p.

MATSUMURA-TUNDISI, T. \& TUNDISI, J. G., 1976, Plankton studies in a lacustrine environment. I. Preliminary data on zooplankton ecology of Broa Reservoir. Oecologia, 25: 265-270.

MATSUMURA-TUNDISI, T., HINO, K. \& CLARO, S. M., 1981, Limnological studies at 23 reservoirs in southern part of Brazil. Verh. Internat. Verein. Limnol., 21: 1040-1047.

MATSUMURA-TUNDISI, T., HINO, K. \& ROCHA, O., 1986, Características limnológicas da lagoa do Taquaral (Campinas, SP) - um ambiente hipereutrófico. Ciência e Cultura, 38(3): 420-425.

MATSUMURA-TUNDISI, T., LEITÃO, S. N., AGHENA, L. S. \& MIYAHARA, J., 1990, Eutrofização da represa de Barra Bonita: estrutura e organização da comunidade de Rotifera. Rev. Brasil. Biol., 50(4): 923-935.

MATSUMURA-TUNDISI, T., ROCHA, O. \& TUNDISI, J. G., 1997, Carbon uptake by Scolodiaptomus corderoi and Thermocyclops minutus feeding on different size fractions of phytoplankton from Lake Dom Helvécio, pp. 275-284. In: J. G. Tundisi \& Y. Saijo (eds.), Limnological studies on the Rio Doce Valley Lakes, Brazil. Brazilian Academy of Sciences/University of São Paulo, School of Engineering at São Carlos/Center for Water Resources and Applied Ecology, São Carlos, 528p.

NOGUEIRA, M. G. \& MATSUMURA-TUNDISI, T., 1996, Limnologia de um sistema artificial raso (Represa do Monjolinho - São Carlos, SP). Dinâmica das populações planctônicas. Acta Limnol. Brasil., 8: 149-168. 
NOGUEIRA, M. G. \& PANARELLI, E., 1997, Estudo da migração vertical da populações zooplanctônicas na represa de Jurumirim (Rio Paranapanema - São Paulo, Brasil). Acta Limnol. Bras., 9: 55-81.

PATALAS, K., 1971, Crustacean plankton communities in forty-five lakes in the Experimental Lakes Area, northwestern Ontario. J. Fish. Res. Bd. Can., 28: 231-244.

PEJLER, B., 1983, Zooplanktic indicators of trophy and their food. Hydrobiologia, 101: 111-114.

PIELOU, E. C., 1975, Ecological diversity. John Wiley, New York, $165 \mathrm{p}$.

PINTO-COELHO, R. M., NUNES, C. M., BARBEITOS, M., MORAES, C. A. \& GUERRA, S. T., 1998, O impacto da Refinaria Gabriel Passos na estruturação da comunidade zooplanctônica no reservatório de Ibirité, Betim, Minas Gerais. Bios., 6: 11-19.

REID, J. \& PINTO-COELHO, R. M., 1994, Planktonic Copepoda of Furnas Reservoir: initial survey of species (1993) and review of literature, pp. 93-114. In: R. M. Pinto-Coelho, A. Giani \& E. Von Sperling (eds.), Ecology and human impact on lakes and reservoirs in Minas Gerais with special reference to future development and management strategies. SEGRAC, Belo Horizonte, 193p.

RIETZLER, A. C., 1995, Alimentação, ciclo de vida e análise da coexistência de espécies de Cyclopoida na represa de Barra Bonita, São Paulo. Tese de Doutorado, Escola de Engenharia de São Carlos, Unviversidade de São Paulo, 385p.

ROCHA, O., SENDACZ, S. \& MATSUMURA-TUNDISI, T., 1995, Composition, biomass and productivity of zooplankton in natural lakes and reservoirs in Brazil, pp. 151-166. In: J. G. Tundisi, C. E. M. Bicudo \& T. Matsumura-Tundisi (eds.), Limology in Brazil. ABC/SBL, Rio de Janeiro, 376p.

ROCHA, O., MATSUMURA-TUNDISI, T., ESPÍNDOLA, E. L. G., ROCHE, K. F. \& RIETZLER, A. C., 1999, Ecological theory applied to reservoir zooplankton, pp. 457-476. In: J. G. Tundisi \& M. Straškraba (eds.), Theoretical reservoir ecology and its applications. International Institute of Ecology/Backhuys Publishers, São Carlos, 592p.

SAMPAIO, E. V., 1989, Composição e abundância de cladóceros em 23 reservatórios do Estado de São Paulo. Monografia de Graduação, Universidade Federal de São Carlos, 81p.

SAMPAIO, E. V. \& LÓPEZ, C. M., in the press. Nychthemeral variation of some limnological variables in one arm of the Três Marias Reservoir (São Francisco river basin, MG, Brazil) and zooplankton community composition. Bios, 8.

SENDACZ, S. \& KUBO, E., 1999, Zooplâncton de reservatórios do Alto Tietê, pp. 509-530. In: R. Henry (ed.), Ecologia de reservatórios: estrutura, função e aspectos sociais. Botucatu, FUNDIBIO/FAPESP, 799p.

SENDACZ, S., KUBO, E. \& CESTAROLLI, M. A., 1985, Limnologia de reservatórios do sudeste do Estado de São Paulo, Brasil. VIII. Zooplâncton. B. Inst. Pesca, 12(1): 187-207.
SILVA, W. M., 1998, Caracterização do reservatório de Nova Ponte (MG) nos meses de julho (seca) e fevereiro (chuvoso) com ênfase na composição e distribuição do zooplâncton. Dissertação de Mestrado, Escola de Engenharia de São Carlos, Unviversidade de São Paulo, 101p.

SMITH, D. W. \& COOPER, S. D., 1982, Competition among Cladocera. Ecology, 63(4): 1004-1015.

SNEATH, P. H. A. \& SOKAL, R. R., 1973, Numerical taxonomy. Freeman, San Francisco, 573p.

SØRENSEN, T., 1948, A method of establishing groups of equal amplitude in plant sociology based on similarity of species content and its application to analyses of vegetation on Danish commons. Biol. Skr., 5: 1-34.

SPRULES, W. G., 1975, Zooplankton in acid-stressed lakes. J. Fish. Res. Bd. Can., 32(3): 390-395.

STARKWEATHER, P. L., 1980, Aspects of the feeding behavior and trophic ecology of suspension-feeding rotifers. Hydrobiologia, 73: 63-72.

STRAŠKRABA, M. \& TUNDISI, J. G., 2000, Gerenciamento da qualidade da água de represas. ILEC, IEE, São Carlos, 280p.

TUNDISI, J. G., 1981, Typology of reservoirs in Southern Brazil. Verh. Internat. Verein. Limnol., 21: 1031-1039.

TUNDISI, J. G. \& MATSUMURA-TUNDISI, T., 1986, Trophic state index for 23 reservoirs in S. Paulo State southern Brazil. Proceedings of Fifth Science and Technology Japan-Brazil Symposium, pp. 44-53.

TUNDISI, J. G. \& MATSUMURA-TUNDISI, T., 1994, Plankton diversity in a warm monomitic lake (Dom Helvécio, Minas Gerais) and a polymitic reservoir (Barra Bonita): a comparative analysis of the intermediate disturbance hypothesis. An. Acad. Bras. Ci., 66: 15-28.

TUNDISI, J. G., MATSUMURA-TUNDISI, T., HENRY, R., ROCHA, O. \& HINO, K., 1988, Comparações do estado trófico de 23 reservatórios do Estado de São Paulo: eutrofização e manejo, pp. 165-204. In: J. G. Tundisi (ed.), Limnologia e manejo de represas. Série Monografias em Limnologia, EESC-USP, CRHEA, ACIESP, São Carlos, 1ำ vol., 1ํo tomo, 506p.

TUNDISI, J. G., MATSUMURA-TUNDISI, T. \& ROCHA. O., 1999, Theoretical basis for reservoir management, pp. 505-528. In: J. G. Tundisi \& M. Straškraba (eds.), Theoretical reservoir ecology and its applications. International Institute of Ecology/Backhuys Publishers, São Carlos, 592p.

WETZEL, R. G., 1983, Limnology. Saunders College Publishing House, Philadelphia, 767p.

ZARET, T. M., 1980, Predation and freshwater communities. Yale University Press, New Haven, 187p. 